\title{
METHODS OF SYNTHESIS AND PROPERTIES OF THIAZOLOPYRIDINES
}

\author{
T.I.Chaban
}

Lviv National Medical University named after Danylo Halytsky

Key words: thiazolopyridine; synthesis; properties; condensed; pharmacological activity

The review systematizes the theoretical and experimental data concerning methods of synthesis of condensed thiazolopyridines, which at present have been insufficiently studied, the prospects for their application in the directed synthesis of new physiologically active substances. The recent developments in their pharmacology have been also analyzed. The available methods for the synthesis of condensed thiazolopyridines can be divided into two fundamentally different approaches. The first approach is based on annelation of the thiazolidine or thiazole cycle to the pyridine ring, and the second one use pyridine derivatives as starting materials; their functional groups make it possible to change the pyridine ring. Methods for obtaining thiazolopyridines using solid media carriers, and their synthesis with domino reactions deserve a particular attention. Generalization of the scientific data published confirms that the condensed thiazolopyridines exhibit various biological effects. In particular, they are characterized by analgesic, anti-inflammatory, antimicrobial, antioxidant and antifungal activities. Due to the inhibitory action on integrally linked kinase the specified class of compounds can eliminate the hyperproliferative disorders in the living organisms. It has been found that these derivatives exhibit the antidiabetic, antibacterial and anti-tuberculosis action. It is known that derivatives of thiazolopyridines have shown a positive effect in the treatment of sexual dysfunction. Thiazolopyridine derivatives containing the $\alpha$-amino phosphonate residue at 2 position of the basic heterocycle exhibit a significant anticancer effect.

\begin{abstract}
МЕТОДИ СИНТЕЗУ ТА ВЛАСТИВОСТІ ТІАЗОЛОПІРИДИНІВ
T.І.Чабан

Ключові слова: тіазолопіридини; синтез; властивості; анелювання; фрармакологічна активність

В огляді систематизовано теоретичний та експериментальний матеріал з методів синтезу маловивчених на сьогодні конденсованих тіазолопіридинів, перспективи їх використання при спрямованому синтезі нових фрізіологічно активних речовин, а також проаналізовані останні досягнення у фрармакології зазначеної групи гетероциклів. Існуючі методи синтезу конденсованих тіазолопіридинів можна умовно поділити на два принципово різних підходи, перший з яких грунтується на анелюванні тіазолідинового або тіазольного циклу до піридинового ядра, а за другим способом як вихідні речовини використовують похідні піридину, функціональні групи яких дають можливість добудувати ядро піридину. Заслуговують на увагу способи добування тіазолопіридинів з використанням твердофразних носіїв, а також їх синтез із застосуванням методів доміно-реакцій. Узагальнення літературних даних дають підстави стверджувати, що для конденсованих тіазолопіридинів властива різнопланова біологічна активність. Зокрема, для них характерними $є$ аналгетична, протизапальна, антимікробна, антиоксидантна та протигрибкова активність. За рахунок інгібуючої дії на інтегрально зв'язану кіназу, вказаний клас сполук здатен усувати гіперпроліферативні порушення у живих організмах. Встановлено, що зазначені похідні проявляють протидіабетичну, антибактеріальну та протитуберкульозну дію. Відомо, що похідні тіазолопіридинів виявили позитивний ефрект для усунення статевої дисфрункції. Також похідні тіазолопіридину, які вмішують у положенні 2 базового гетероциклу $\alpha$-амінофросфонатний залишок, виявляють значний протираковий ефект.
\end{abstract}

\section{МЕТОДЫ СИНТЕЗА И СВОЙСТВА ТИАЗОЛОПИРИДИНОВ \\ Т.И.Чабан}

Ключевые слова: тиазолопиридины; синтез; свойства; аннелирование; фрармакологическая активность В обзоре систематизированы теоретический и экспериментальный материал по методам синтеза малоизученных на сегодня конденсированных тиазолопиридинов, перспективы их использования при направленном синтезе новых фризиологически активных веществ, а также проанализированы последние достижения в фрармакологии указанной группы гетероциклов. Существующие методы синтеза конденсированных тиазолопиридинов можно условно разделить на два принципиально разных подхода, первый из которых основан на аннелировании тиазолидинового или тиазольного цикла к пиридиновому ядру, а по второму способу в качестве исходных веществ используют производные пиридина, фрункциональные группы которых дают возможность достраивать ядро пиридина. Заслуживают внимания способы получения тиазолопиридинов с использованием твердофазных носителей, а также их синтез с применением методов домино реакций. Обобщение литературных данных дает основание утверждать, что для конденсированных тиазолопиридинов свойственна разноплановая биологическая активность. В частности, для них характерны анальгетическая, противовоспалительная, антимикробная, антиоксидантная и противогрибковая активность. За счет ингибирующего действия на интегрально связанную киназу указанный класс соединений способен устранять гиперпролиферативные нарушения в живых организмах. Установлено, что указанные производные проявляют противодиабетическое, антибактериальное и противотуберкулезное действие. Известно, что производные тиазолопиридинов проявили положительный эфрфект для устранения половой дисфункции. Также производные тиазолопиридина, содержащие в положении 2 базового гетероцикла $\alpha$-аминофоосфонатный остаток, проявляют значительный противораковый эффрект. 


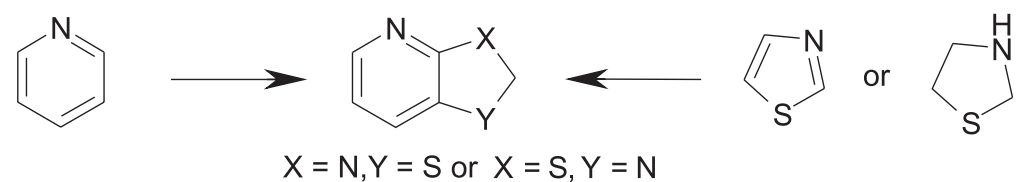

Scheme 1<smiles>N=C1CSC(=O)N1</smiles>

Scheme 2

The fundamental aspects of chemistry and pharmacology of 4-thiazolidones were elucidated in a number of review publications $[1,2,3,4]$, while the information concerning the chemistry of fused thiazoles with the exception for condensed benzothiazoles possessed a sporadic character. Thiazolopyridines are also insufficiently studied, while they are of greater interest from the point of their physiological action if compared with their monocyclic constituents.

There are two fundamentally different methods of the thiazolopyridine system construction. The first method is based on annelation of the thiazolidine or thiazole cycle to the pyridine ring. As to the second one, the pyridine derivatives are used as precursors for the thiazole ring construction on account of their functional groups (Scheme 1).

Methods for the synthesis of thiazolopyridines by modification of thiazolidone- 4 and thiazole derivatives. The convenient method for the syn- thesis of $3 H$-thiazolo[4,5-b]pyridine-2-one derivatives is the use of 4-iminothiazolidin-2-one as a starting substance firstly obtained by I.D. Komaritsa by heating iso-rhodanine with $25 \% \mathrm{NH}_{4} \mathrm{OH}$ [6] (Scheme 2).

The interaction of the substance mentioned above with some $\beta$-carbonyl compounds leads to formation of the hard-to-get $3 \mathrm{H}$-thiazolo[4,5- $b]$ pyridines with the yield of 79-100\% [7-10] (Scheme 3).

One of the methods of the pyridine cycle annelation to the thiazole ring is based on the three-component condensation of 4-aminothiazole derivatives with both aromatic or aliphatic aldehydes and Meldrum acid. The yield of the target products is equal to $44-65 \%$ [11-15] (Scheme 4).

The cyclization of 4-formylamino-5-acyl substituted thiazoles either with bases or with acetic acid leads to 7-hydroxy-2-(methylsylfanyl)-thiazolo[4,5-b] pyridines with the yield of 70\% [16] (Scheme 5).

Under the condensation of 4-amino-5-benzoyl2-phenylthiazoperchlorate with ketones at $130-150^{\circ} \mathrm{C}$, thiazolo[4,5-b]pyridines with the yields of $46-64 \%$ are formed [17] (Scheme 6).

5-Aminothiazoles with the unoccupied $\mathrm{C}^{4}$ position can interact with diethyletoximethylenemalonate forming the intermediate, which when heating<smiles>[R]c1c(C)nc2[nH]c(=O)sc2c1C</smiles><smiles>N=C1CSC(=O)N1</smiles><smiles>[R]C(C(C)=O)C(=O)OCC</smiles><smiles>[R]c1c(O)nc2[nH]c(=O)sc2c1C</smiles>

Scheme 3

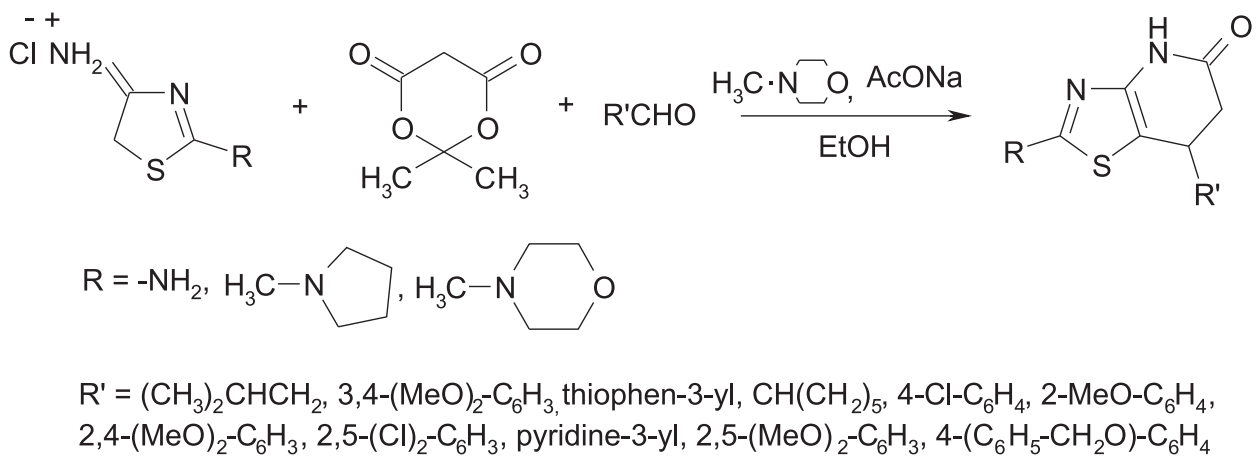

Scheme 4<smiles>CCOC(=O)CC(=O)c1sc(C)nc1NC=O</smiles><smiles>CCOC(=O)c1cnc2nc(S(C)(C)C)sc2c1O</smiles> 
<smiles>[R]CC(C)=O</smiles>

Scheme 6<smiles>CCOC(=O)C(=CNc1cnc(SCCCCOc2ccccc2)s1)C(=O)OCC</smiles>

Scheme 7<smiles></smiles>

Scheme 8

undergoes cyclization to form thiazolopyridine with the yield of $90 \%$, while in interaction with $\mathrm{POCl}_{3}$, the chlorine derivative of this thiazolopyridine is obtained with the yield of 53\% [18] (Scheme 7).

Isocyanate is commonly prepared by heating 2(E)-3-(2-phenyl-1,3-thiazole-4-yl)acryliozide in biphenyl ether, then it is cyclized into phenylthiazolopyridine-4-ol with the yield that exceeds the level of 90\% [19] (Scheme 8).

Due to the interaction of bis(methylthio) methylenemalonononitrile with 4-amino-2-phenylthiazole, thiazolopyridine is obtained [20] (Scheme 9).

The use of acetoacetic ether in the reaction with 2,4-diamino-thiazoles and acetylacetone, 2-amino7-5,7-dimethylthiazolo[4,5- $b]$ pyridine and 2-amino7-methyl-4H-thiazolo[4,5- $b]$ pyridine-5-ones were obtained [21] (Scheme 10).
The accessible method for obtaining of thiazolo [4,5-b]pyridines is the use of 2-(5-aryliden-4-oxo-2thioxothiazolidine-3-ilamino)-N-aryl-2-thioxoacetamides as the starting substances. When boiling the given derivatives with ethyl cyanoacetate in the ammonium acetate solution in acetic acid within 4 hours, the substituted 2-thioxothiazolopyridine-6-carbonitryls are obtained with the yields of $50-55 \%$. The yields of the abovementioned heterocycles may be considerably increased with the use of micro-wave irradiation. While carrying out this particular reaction and due to the micro-wave irradiation the corresponding 5-oxo-2thioxo-6-cyano-4,5,6,7-tetra-hydrothiazolo[4,5- $b]$ pyridines are prepared with the yield of $88-92 \%$ [22, 23] (Scheme 11).

Among the methods of the thiazolo[4,5-b]pyridine system construction, the cyclocondensation based<smiles>CSC(C)=C(C#N)C#N</smiles><smiles>CS(=O)(=O)c1nc2nc(-c3ccccc3)sc2c(N)c1C#N</smiles>

Scheme 9<smiles>[R10]Nc1nc2c(s1)C(C)C(C)C(C)=C2C(C)=O</smiles><smiles>[R2]NC1=NC(=NC)CS1</smiles><smiles>[R2]Nc1nc2c(s1)C(C)CC(C)N2</smiles>

Scheme 10 
<smiles>[R]c1ccccc1NC(=O)C(N)=S</smiles>

$\mathrm{R}=\mathrm{H}, 4-\mathrm{Cl}, 4-\mathrm{OMe}$<smiles>[X]C(C(=O)OCC)C(=O)OCC</smiles>
$88-92 \%$<smiles>[R]c1ccccc1NC(=O)C(=S)Nn1c2c(sc1=S)C(c1ccccc1)C(C#N)C(=O)N2</smiles>

Scheme 11<smiles></smiles><smiles>CCOC(=O)CC(C)=O</smiles><smiles>CCOC(=O)c1c(C)nc2c(s/c(=N\C(=N/c3ccccc3)c3ccc(OC)cc3)n2-c2ccccc2)c1N</smiles>

Scheme 12

on the substituted 4-amino-5cyano-2,3-dihydro-1,31,3-triazoles proceeding with the participation of the enaminonitrile fragment is worth noting [24-25]. The abovementioned reaction is carried out when heating $\mathrm{N}$-(5-amino-4-cyano-3-phenyl-3H-thiazolo-2-ilden)4-metoxo-N-N-phenylbezamidine with the aceto-acetic ester or cyclohexanone in the presence of tin tetrachloride in 1,2-dichloroethane within 5-6 hours and results in formation of ethyl ester of 7-amino-2-(4methoxo-N-phenyl-benzimidoilmino)-5-methyl-3phenyl-2,3-dihydrothiazole[4,5-b]pyridine-6-carboxylic acid with the yields greater than $80 \%$ (Scheme 12).

Taking into account the interaction of 6-(4-chlorophenyl)-3-phenylthiazolo[4,5-e][1,2,4]triazene with bicyclo[2,2,1]hepta-2,5-diene, M.M.Krayushkin with co-authors $[26,27]$ initiated an original method of synthesis of the problematic thiazolopyridines. This reaction is carried out under high pressure in the presense of lithium perchlorate as a catalyst. The yield of 2-(4-chlorophenyl)-5phenylthiazolo[4,5-b]pyridine in this case is equal to $97 \%$ (Scheme 13).

V.O.Iaroshenko and co-authors [28] in order to obtain thiazolopyridines suggested the interaction of
2-aminothiazole-4(5H)-imine salts with different 1,3CCC-dielectrophils; it led to the target compounds with the yields in the range of $14-85 \%$ (Scheme 14).

A great number of reactions of conjugated thiolatonitriles with 2-bromide-1-arylethylidenemalononitriles leads to obtaining 2,5-diamino-7-phenylthiazolo[4,5-b]pyridine-6-carbonitrile derivatives with high yields $[29,30]$ (Scheme 15).

Methods of the thiazolopyridine synthesis by transformation of pyridine derivatives. The structure of the thiazolidine ring by means of cyclization of the functional groups of pyridine that results in formation of thiazolopyridines is widely elucidated and represented in a vast majority of publications.

The interaction of 2-mercapto-3-aminopyridines obtained from the corresponding chloraminopyridines with acids or with their anhydrides results in thiazolopyridines formation with the yields of 60 $70 \%[31,32]$ (Scheme 16).

While carrying out the reactions of 3-amino-2chlorpyridines with ortho-alkylthiocarboxylic acids esters at first the amino group is activated by N-methylation with ethylmagnesiumbromide, butyllithium<smiles>Clc1ccc(-c2nc3nc(-c4ccccc4)nnc3s2)cc1</smiles>

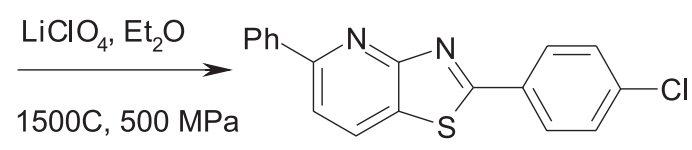

Scheme 13

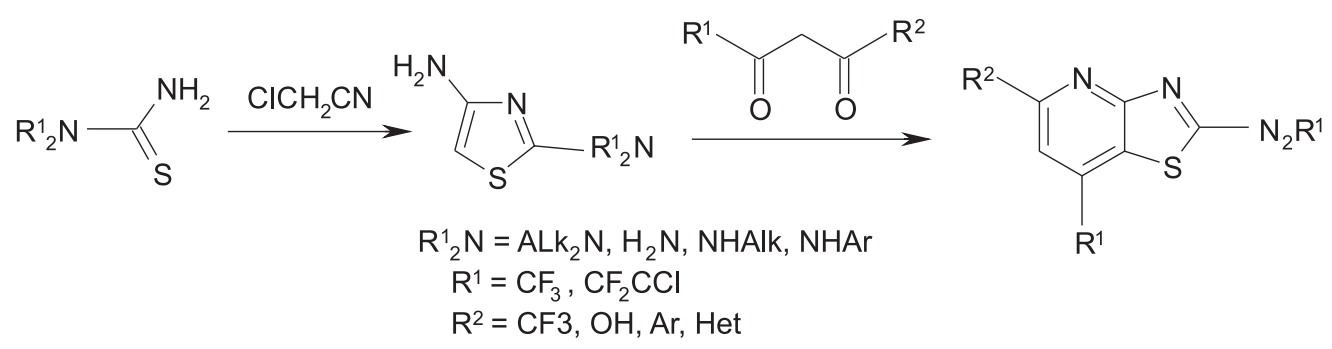




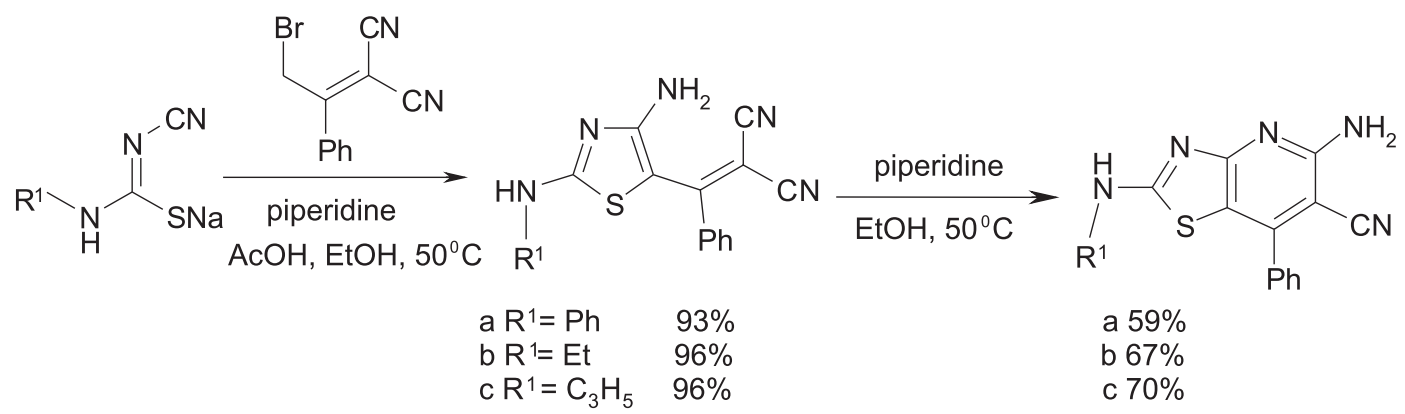

Scheme 15<smiles></smiles>

Scheme 16

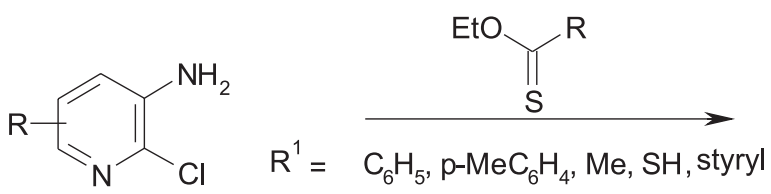<smiles>[R]c1ccc2nc([R])sc2n1</smiles>

Scheme 17

or sodium hydride, then it is treated by thioesters. The yields of the target compounds in this case are equal to 70\% [33-35] (Scheme 17).

Thioureas obtained from aminochlorpyridines and alkyl-, aryl- or ethoxycarbonyl isothiocyanate undergo further cyclization with the chlorine atom replacement. The yields of the final thiazolopyridines are equal to 60-70\% [36-38] (Scheme 18).

Thiazolopyridines were obtained from thiourea of pyridine series when treating with bromine generated with $\mathrm{HBr}$ in DMSO [39] (Scheme 19).

5-Amino-2-chlorpyridine is transformed into 2aminothiazolopyridine with the yield of $91 \%$ by means

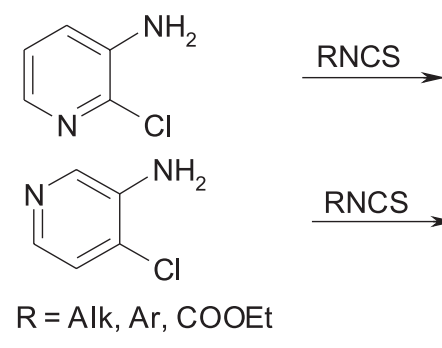

of interaction with sodium rhodanide in the presence of bromine in acetic acid [40] (Scheme 20).

The interaction of 3-amino- $1 H$-tetrazol-5-ylsulfanilsubstituted pyridines with hydrochloric acid in ethanol results in formation of 2-aminothiazolo[5,4- $b]$ pyridines with the yield of 40-80\% [38] (Scheme 21).

In cyclization of pyridyldithiocarbomates with alkalis in ethanol the mixture of thiazolopyridinthiol $(86 \%)$ and $\mathrm{N}, \mathrm{N}$-diisopropylthiazolopyridin-2-amine $(14 \%)[41,42]$ is obtained (Scheme 22).

As the result of ortho-amino(diisopropyldithiocarbomato)pyridines treatment with carboxylic acid in the presence of $\mathrm{POCl}_{3}$, thiazolo[4,5-b] pyridines or

Scheme 18<smiles>NC(=S)Nc1ccnc(N2CCOCC2)c1</smiles>

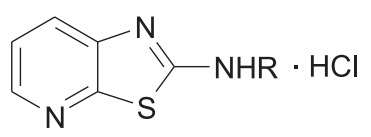<smiles>[R]Nc1nc2cnccc2s1</smiles>

Scheme 18<smiles>Nc1nc2ccnc(N3CCOCC3)c2s1</smiles>

Scheme 19<smiles>Nc1ccc(Cl)nc1</smiles><smiles>O=C(O)CCCC(=O)OS(=O)(=O)Br</smiles><smiles>Nc1nc2ccc(Cl)nc2s1</smiles> 


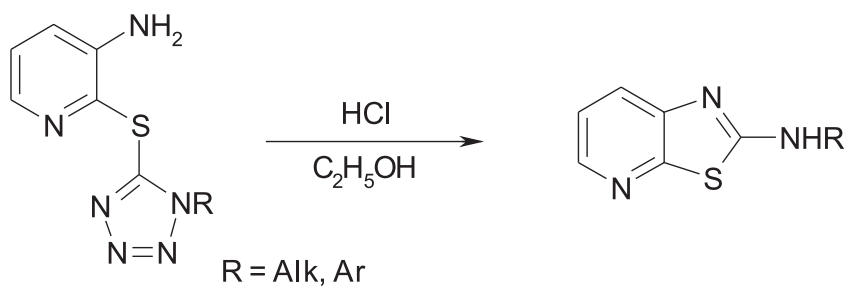

Scheme 21<smiles>CCCCOC(=O)Nc1ccncc1SC(=S)Nc1ccccc1</smiles><smiles>CCC(C)(O)OO</smiles>

Scheme 22

thiazolo[5,4-c]pyridines with moderate yields [43] are obtained (Scheme 23).

Similarly, 2-substituted thiazolo[4,5-b]pyridines are obtained when treating ortho-amino(diisopropyldithiocarbamato)pyridines with acid chlorides in dichlormethane in the presence of triethylamine with subsequent boiling in hydrochloric acid [44].

Thiazolo[5,4-c]pyridine was obtained with the help of a multistage reaction with tert-butyloxycarbonylaminopyridine. The amide cyclization is performed by heating in formic acid with the yield of $20 \%$ [44] (Scheme 24).

Starting with ortho-nitrochlorpyridines, 2-methyl1,3-thiazolo[4,5- $b]$ - and thiazolo[4,5-c]pyridines [40] were obtained. The aim was to determine the effect of their derivatives on the Koch's bacillus $[45,46]$. The reaction occurs via the stage of disulfide formation with its further reduction by zinc. The yields of 2-methyl-1,3-thiazolo[4,5- $b]$ - and thiazolo [4,5-c] pyridines are about 50\% (Scheme 25).<smiles>CC(C)(C)O[P+]([O-])Nc1nc2ccncc2s1</smiles>

One of the promising methods of the thiazolopyridine synthesis is the use of 2-chloro-3-nitropyridine and 4-chloro-3-nitropyridine. K.Walczyn'ski and co-authors [47] while treating the abovementioned compounds by hydrogen sulfide in the aqueous solution of sodium hydroxide in the presence of sodium sulfide and carbon bisulfide were successful in obtaining thiazolopyridine-2-thiones; the methylation of them by methyl iodide in the dimethyl ether ethylene glycol medium results in 2-methylsulfanilthiazolopyridines (Scheme 26).

These authors also suggest to use N-(3-and N-(5diisopropylthiocarbomoyl-pyridine-2-yl)-2,2 dimethyl-propionamides, which in the result of hydrolysis in $20 \%$ ethanol solution of sodium hydroxide form the target thiazolopyridine, while their further methylation leads to the corresponding 2-methylsulfanilthiazolopyridines (Scheme 27).

In order to find the substances with the anticancer activity $\mathrm{Gu}$ L. and co-authors developed the me-

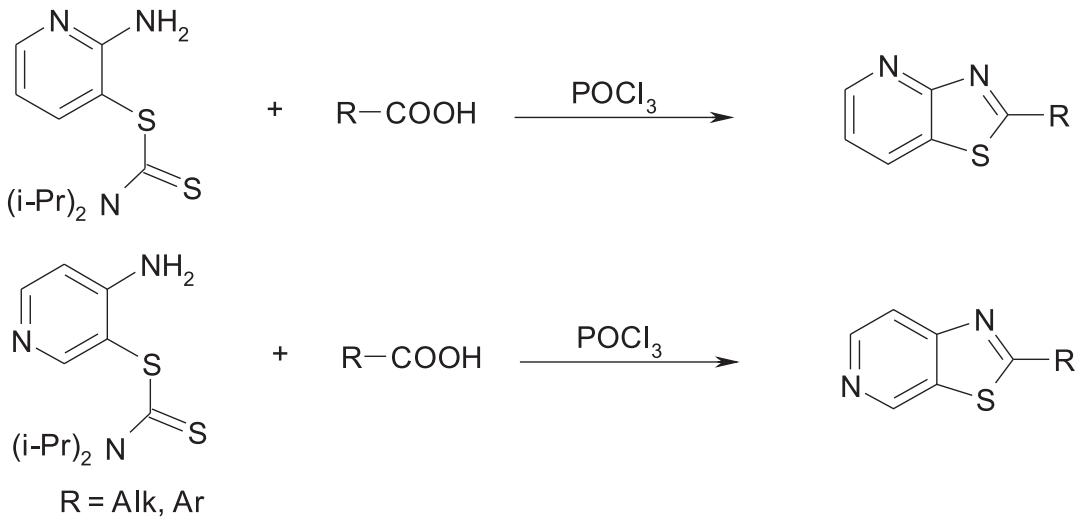

Scheme 23<smiles>CC(C)(C)OC(=O)Nc1ccncc1</smiles> 


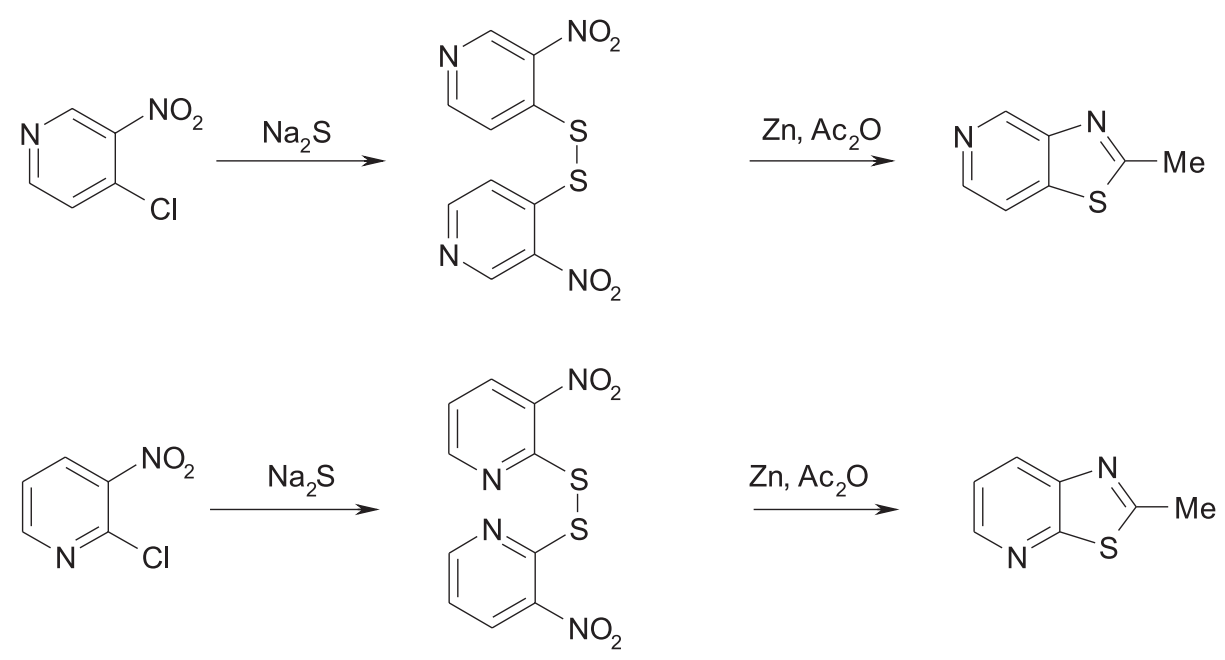

Scheme 25<smiles>O=[N+]([O-])c1cccnc1Cl</smiles><smiles>S=c1[nH]c2cccnc2s1</smiles><smiles>Cc1nc2cccnc2s1</smiles>

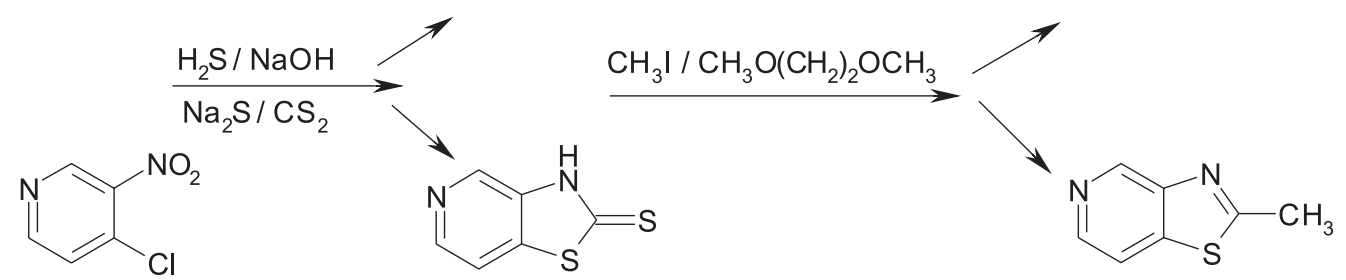

Scheme 26

thod for obtaining thiazolo[5,4-c]pyridine derivatives that contain the $2 \alpha$-aminophosphonate residue. The initial substances used to perform this transformation are 3-nitro-2-brompyridine, 1-aminophosphanate and $\mathrm{CS}_{2}$. The reaction takes place in the DMFA medium in the presence of solutions of $\mathrm{CuCI}_{2} \cdot 2 \mathrm{H}_{2} \mathrm{O}$, $\mathrm{SnCl}_{2} \cdot 2 \mathrm{H}_{2} \mathrm{O}$ and $\mathrm{K}_{2} \mathrm{CO}_{3}$. The yields of the target products are equal to 78-82\% [48] (Scheme 28).
One of the methods to obtain 2-arylthiazolo[5,4- $b]$ pyridines is based on using N-(2-chloro-pyridine-3yl)arylamides [49]. These aryl amides are obtained by acylation of 2-chloro-pyridine-3-ylamine with acyl chlorides of aromatic acids according to Shotten-Bauman reaction. The compounds are subjected to thionation with phosphorus pentasulfide in the pyridine medium or Lawesson's reagent (LR) in the medium of<smiles>CC(C)N(C(=S)c1cnccc1NC(=O)C(C)(C)C)C(C)C</smiles><smiles>S=c1[nH]c2ccncc2s1</smiles><smiles></smiles><smiles>CC(C)N(C(=S)c1cccnc1NC(=O)C(C)(C)C)C(C)C</smiles>
$\mathrm{CH}_{3} \mathrm{I} / \mathrm{CH}_{3} \mathrm{O}\left(\mathrm{CH}_{2}\right)_{2} \mathrm{OCH}_{3}$<smiles>S=c1[nH]c2ncccc2s1</smiles><smiles>CSc1nc2ncccc2s1</smiles>

Scheme 27

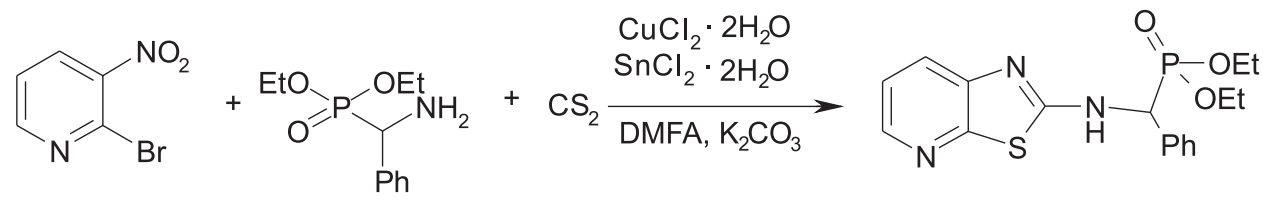




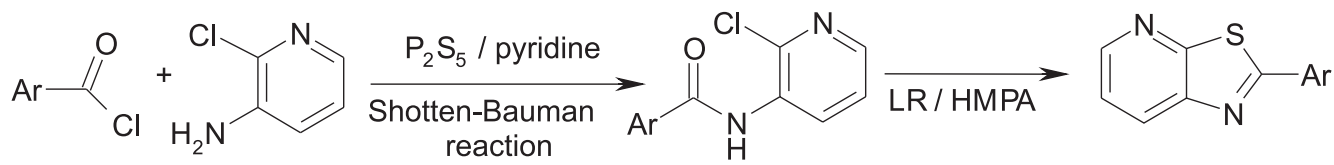

Scheme 29

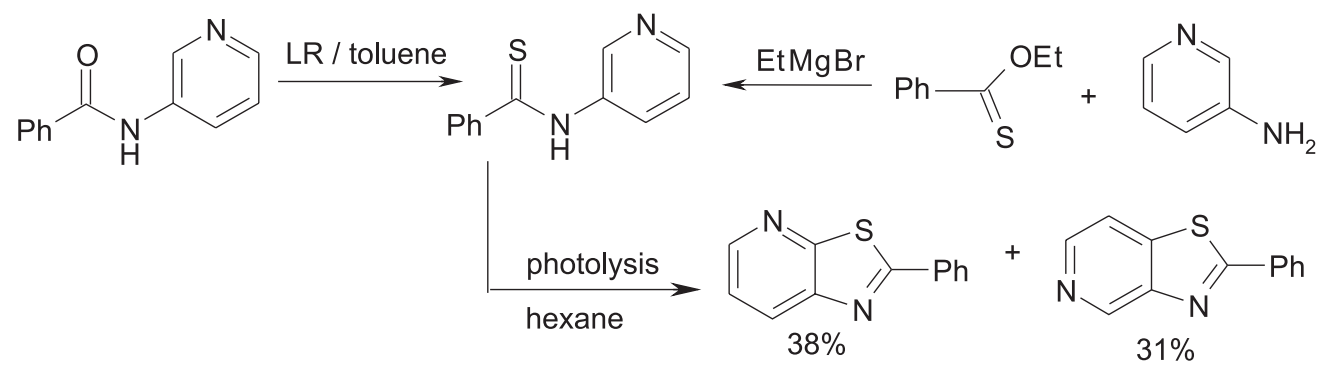

Scheme 30

hexamethylphosphoramide (HMPA) to form 2-arylthiazolo[5,4-b]pyridine (Scheme 29).

The authors underline that the yields of the target products are considerably higher when Lawesson's reagent is applied. Obtaining of the mixture of 2 -aryl thiazolo $[5,4-b]$ pyridines and 2-aryl thiazolo $[4,5-c]$ pyridines by means of photolysis of N-pyridine-3-yl-thioarylamides in the hexane medium is also suggested in the same work. It has been found that the target thioarylamides that perform the function of the initial substances in this reaction may be obtained both by N-pyridine-3-ylaryl amides thionation with the yield of $9 \%$ and by interaction of pyridine-3-yl-amine with thiobenzoate acid ortho-ethyl ether in the presence of Grignard reagent with the yield of $68 \%$ (Scheme 30 ).

Thiazolopyridines were obtained by thioamide pyridine oxidation using hexacianoferrate potassium in the alkaline medium [50] (Scheme 31).

The new approach to formation of thiazolo[4,5-b]pyridines or thiazolo[5,4-b]pyridines systems is based on the method of oxidative cyclization of monothioxamides. In this method $\alpha$-chloracetamides and amino derivatives of pyridine (pyridine-2,6-diamine and pyridine-3-ylamine) are the initial substances, which form monothioxamides at the first stage, and they are oxidized in the $\mathrm{NaOH}$ solution under the action of $\mathrm{K}_{3}\left[\mathrm{Fe}(\mathrm{CN})_{6}\right]$ at $50^{\circ} \mathrm{C}$ with cyclization to the target 5-aminothiazolo[4,5-b]pyridines-2-carboxamides or thiazolo[5,4- $b$ ]pyridines-2-carboxamides [51-54] at the next stage (Scheme 32).

Proceeding from the derivatives of 2-chloropyridine-3-ylamine and (2,4-dihydroxyphenyl)-[(2.4-dihydroxyphenyl)-thioxo-methano-sulfinyl]methanethione using one pot synthesis, (1,3-thiazolo[5,4- $b]$ pyridine-2-yl)benzendiols [55] (Scheme 33).

Synthesis of thiazolo[4,5- $b]$ pyridines using solid-phase carriers. There are also instances of obtaining 1,3-thiazolo[4,5- $b$ ]pyridine derivatives based on using solid-phase carriers [56]. This method is carried out based on Torp Ziegler cyclization at the first stage, and at the next stage - on Friedlander's reaction in the conditions of micro-wave activation with further electrophilic displacement by amines. The given transformations provide obtaining of 2,5, 6,7-tetrasubstituted derivatives of thiazolo[4,5- $b]$ pyridine (Schemes 34, 35).

Synthesis of thiazolo[4,5- $b$ ]pyridines using "domino" reaction methods. The new combinatorial method of obtaining the substituted thiazolo[4,5- $b]$ pyridines has been developed by the Institute of Organic Chemistry named after M.D.Zelinsky. It is based on the use of "domino" reactions of the following type: $\mathrm{S}_{\mathrm{N}} 2 \rightarrow$ Torp Ziegler reaction $\rightarrow$ Guareschi-Thorpe reaction $[57,58]$. The initial substances in this method are cyanoacetamides heterocumulenes (isothiocyana-<smiles></smiles> 


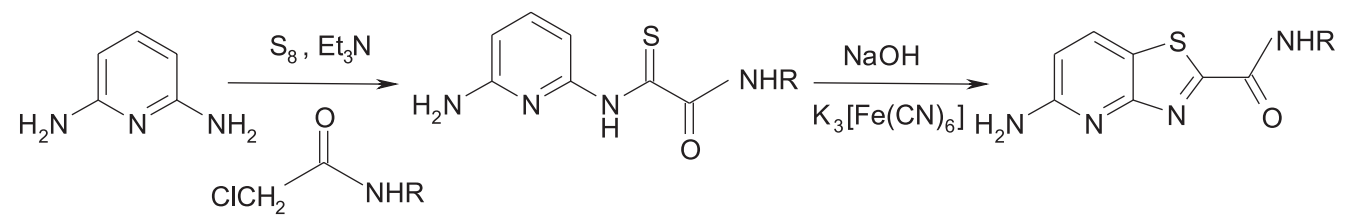

$\mathrm{R}=\mathrm{C}_{6} \mathrm{H}_{5}, 4-\mathrm{BrC}_{6} \mathrm{H}_{4}, 4-\mathrm{ClC}_{6} \mathrm{H}_{4}, 4-\mathrm{FC}_{6} \mathrm{H}_{4}$, 4- $\mathrm{MeC}_{6} \mathrm{H}_{4}, 4-\mathrm{MeOC}_{6} \mathrm{H}_{4}, 2-\mathrm{FC}_{6} \mathrm{H}_{4}$

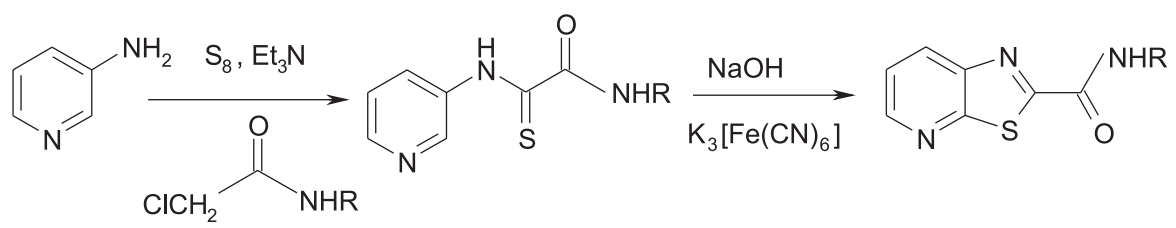

$\mathrm{R}=\mathrm{C}_{6} \mathrm{H}_{5}, 4-\mathrm{FC}_{6} \mathrm{H}_{4}, 2,6-(\mathrm{Me})_{2} \mathrm{C}_{6} \mathrm{H}_{3}, 4-\mathrm{BrC}_{6} \mathrm{H}_{4}$

Scheme 32

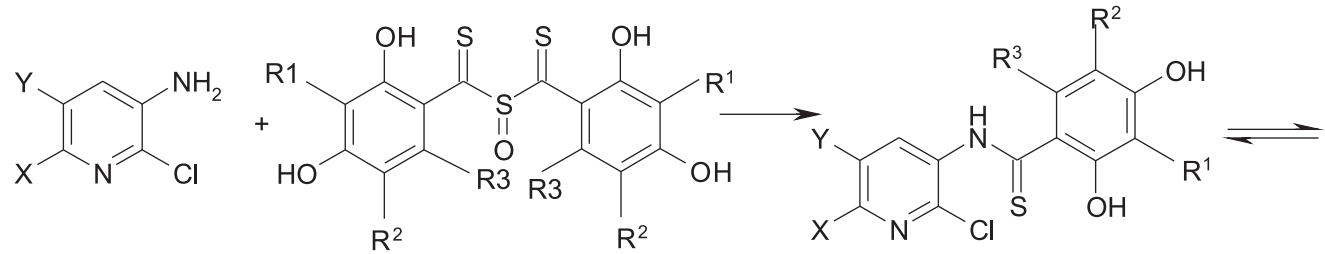<smiles></smiles><smiles>[Y]#[W]</smiles><smiles>[X]c1cc2nc(-c3c([R])c([R])c(O)c([R])c3O)sc2nc1[X]</smiles>

$R^{1}, R^{2}, R^{3}=H, M e, E t, O H, C l$

Scheme 33

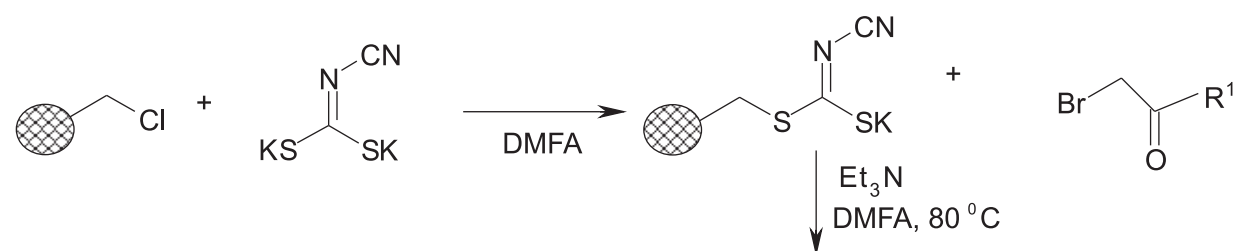<smiles>[R]c1cc2sc(SCC#C)nc2nc1[R]</smiles>

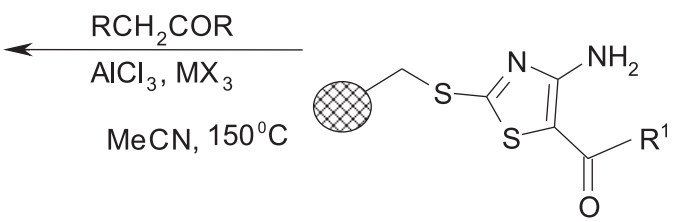<smiles>[R]c1cc2sc(S(=O)(=O)CC#C)nc2nc1[R]</smiles><smiles>[R2]NCCN(CC)[R]([R])[H]</smiles><smiles>[R]c1cc2sc(N([R7])[R7])nc2nc1[R]</smiles>

Scheme 34<smiles>[R]CC([R])=O</smiles> 


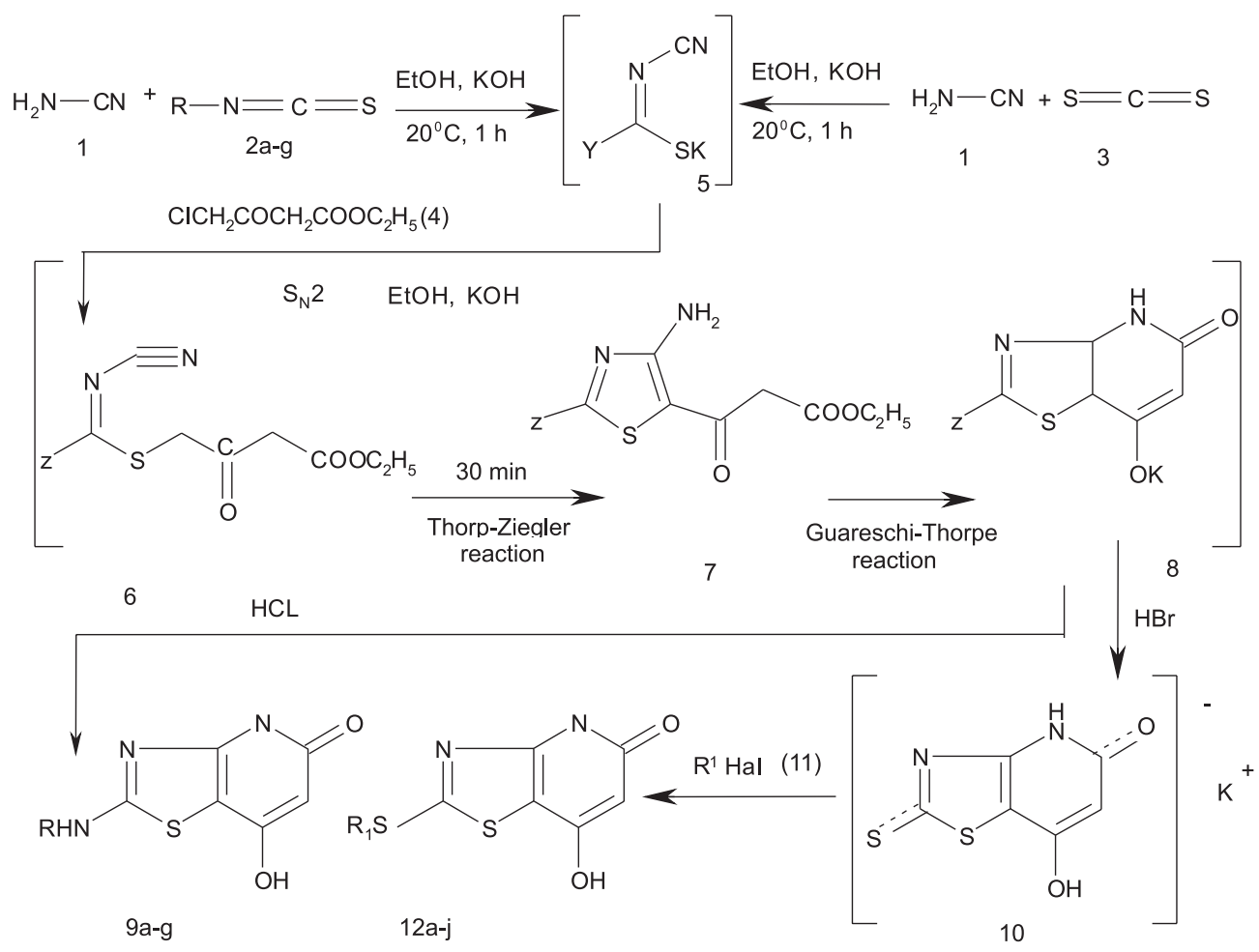

$\mathrm{Z}=\mathrm{NHR}, \mathrm{SK}=2,9: \mathrm{R}=\mathrm{CH}_{3}(\mathrm{a}) ; \mathrm{CH}_{3} \mathrm{CH}_{2}(\mathrm{~b}) ; \mathrm{CH}_{2} \mathrm{CH}-\mathrm{CH}_{2}$ (c); $\mathrm{C}_{6} \mathrm{H}_{5}(\mathrm{~d}) ; 4-\mathrm{OCH}_{3}-\mathrm{C}_{6} \mathrm{H}_{4}$ (e); 3-Cl- $\mathrm{C}_{6} \mathrm{H}_{4}$ (f); 3-F- $\mathrm{C}_{6} \mathrm{H}_{4}$ (g). 11, 12: R1 $=\mathrm{CH}_{3}(\mathrm{a}) ; \mathrm{CH}_{3} \mathrm{CH}_{2}$ (b); $\mathrm{CH}_{2}-3-\mathrm{C}_{5} \mathrm{H}_{4} \mathrm{~N}$ (c); $\mathrm{CH}_{2}-2,6-\mathrm{Cl}_{2}-\mathrm{C}_{6} \mathrm{H}_{3}$ (d); $\mathrm{CH}_{2}-3,4-\mathrm{F}_{2}-\mathrm{C}_{6} \mathrm{H}_{3}(\mathrm{e}) ; \mathrm{CH}_{2}-3-\mathrm{CF}_{3}-\mathrm{C}_{6} \mathrm{H}_{4}$ (f); $\mathrm{CH}_{2}-\mathrm{CO}-3,4-(\mathrm{OCH} 3) 2-\mathrm{C}_{6} \mathrm{H}_{3}(\mathrm{~g}) ; \mathrm{CH}_{2}-\mathrm{CONH}-\mathrm{Ad} 1$ (h); $\mathrm{CH}_{2}-\mathrm{CONH}-3,4-\mathrm{F}_{2}-\mathrm{C}_{6} \mathrm{H}_{3}(\mathrm{i}) ; \mathrm{CH}_{2}-\mathrm{CONH}-2-\mathrm{CF}_{3}-\mathrm{C}_{6} \mathrm{H}_{4}(\mathrm{j})$.

Scheme 36

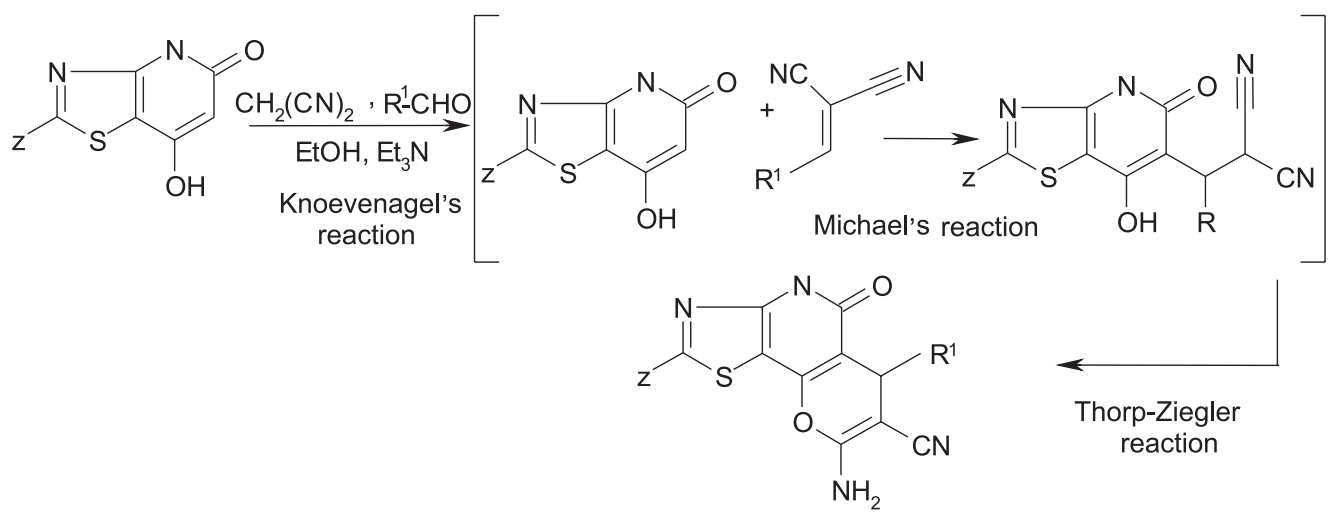

Scheme 37

tes, sulfur carbonate) and ethyl-4-chloracetylacetate, which are able to form the target thiazolo[4,5- $b]$ pyridines due to "domino" reactions (Scheme 36).

The products obtained are used with aldehydes and malononitrile in another "domino" reaction of the type: Knoevenagel's reaction $\rightarrow$ Michael's reaction $\rightarrow$ Torp Ziegler reaction for the synthesis of the substituted 4,6-dihydro-5H-pyrano[2,3- $d$ ] thiazolo[4,5-b] pyridines (Scheme 37).

Pharmacological effects. The combination of combinatory chemistry and highly effective pharmacological screening has made possible identification of a large group of cell biotargets. The abovementioned fact promoted to more effective study and understanding of the details of the mechanism of action of phar- macological agents, as well as the considerable expansion of chemical compounds as potential drugs. The application of the aforementioned strategy has become a key factor in the rapid development of the pharmacological potential of the condensed thiazole and thiazolidone derivatives and allowed to discover new pharmacological effects of the given compounds, as well as further develop the peculiarities of the mechanisms of action revealed earlier due to the detailed elaboration at the "ligand - receptor" level.

Thus, thiazolopyridine derivatives demonstrate the analgesic, anti-inflammatory, antimicrobial and antifungal $[8,59-64])$ activities. Due to the inhibitory action on integrally linked kinase the specified class of compounds can eliminate the hyperprolifera- 
tive disorders in the living organisms [65-67]. The antidiabetic [68], antibacterial [69], antituberculosis [70], anti-inflammatory [71, 72] effects were determined. It is known that thiazolopyridine derivatives show a positive effect in the treatment of the sex dysfunction [73]. Among this type of compounds there are substances that act as agonists of H3-histamine receptors [48], antagonists of metabotropic glutamate receptors 5 (mGLuR5) [74] with a high inhibitory activity in relation to receptors of the epidermal growth factor [75] and a number of other enzymes [76, 77]. Gu L. and co-authors have found that thiazolopyridine derivatives, which contain the $\alpha$-amino phosphonate residue in position 2 of the basic heterocycle, possess a considerable anticancer effect [49]. The antioxidant activity is also typical for the aforementioned class of compounds.

\section{Conclusions}

The analysis and systematization of the literature references have been performed concerning the methods of synthesis and properties of thiazolopyridines. Thus, wide synthetic opportunities and their high pharmacological potential have been proven to be the indisputable reasons for the systematic research of the type of compounds described.

\section{References}

1. Brown F. C. Chemical Reviews, 1961, Vol. 61, No.5, pp.463-521.

2. Singh S. P., Parmar S. S., Raman K. et. al. Chemical Reviews, 1981, Vol. 81, No.2, pp.175-203.

3. Zimenkovsky B. S., Lesyk R. B. 4-Thiazolidony. Chimiya, fiziologichna diya, perspektyvy (4-Thiazolidones. Chemistry, physiological action, perspectives). Vinnycya, Nova knyga, 2004, 106 p.

4. Lesyk R. B., Zimenkovsky B. S. Current Organic Chemistry, 2004, Vol. 8, No.16, pp.1547-1579.

5. Komaritsa I. D. Chemistry of Heterocyclic Compound, 1968, No.3, pp.436-437.

6. Komaritsa I. D. Chemistry of Heterocyclic Compound, 1989, No.11, pp.1547-1549.

7. Chaban T. I., Zimenkovskii B. S., Komaritsa I. D. et. al. Russ. J. Org. Chem., 2012, Vol. 48, Issue 2, pp.268-270.

8. Chaban T. I., Ogurtsov V. V., Chaban I. G. et al. Zhurnal organichnoi ta farmacevtichnoi khimii - Journal of organic and pharmaceutical chemistry, 2012, Vol. 10, No.2(38), pp.70-76.

9. Chaban T. I., Panchuk R. R., Klenina O. V. et al. Biopolymers and Cell, 2012, Vol. 28, No.5, pp.389-396.

10. Chaban T. I., Ogurtsov V. V., Chaban I. G. et al. Phosphorus, Sulfur, and Silicon and the Related Elements, 2013, Vol. 188, pp.1611-1620.

11. Dudinov A. A., Lichitsky B. V., Antonov I. A. et al. Russian Chemical Bulletin., 2008, No.8, pp.1707-1710.

12. Lichitsky B., Komogortsev A., Dudinov A. et al. The 5th Eurasian Meeting on Heterocyclic Chemistry, Book of abstracts, 2008, Kuwait, p.124.

13. Lichitsky B., Komogortsev A., Dudinov A. et al. The 23nd International Symposium on the Organic Chemistry of Sulfur, Abstracts, 2008, Moscow, pp.100-102.

14. Lichitsky B., Komogortsev A., Dudinov A. et al. The III Youth conference Institute of organic Chemistry Russian Academy of Sciences, 2009, Moscow, U4-15-17.

15. Комогорцев А. Н. Трехкомпонентная конденсация гетероциклических аминов с карбонильными соединениями и кислотой Мельдрума: автореф. дисс. на соискание ученой степени канд. хим. наук: спец. 02.00 .03 «Органическая химия» / А. Н. Комогорцев. - Москва, 2009. - 26 с.

16. Hayakawa I., Tanaka Y. Heterocycles, 1984, Vol. 22, No.8, pp. 1697-1700.

17. Schäfer H., Hartmann H., Gewald K. J. Prakt. Chem., 1974, Vol. 316, No.1, pp.19-25.

18. Leysen D. C., Haemers A., Bollaert W. J. Het. Chem., 1984, Vol. 21, No.2, pp.401-406.

19. Shafiee A., Ghazar H. J. Het. Chem., 1986, Vol. 23, No.4, pp.1171-1173.

20. El-Sayed I. El-Desoky, Aboul-Fetouh S., Metwally M. A. J. Chem. Tech. \& Biotechnol., 1996, Vol. 67, No.2, pp.153-156.

21. Flaig R., Hartmann H. Monatshefte für Chemie, 1997, Vol. 128, No.10, pp.1051-1060.

22. Yarovenko V. N., Nikitin A. S., Zavarzyn I. V. et al. Zhurnal organicheskoi khimii, 2007, Vol. 43, No.9, pp.1368-1374.

23. Никитина А. С. Синтез гетероциклических соединений на основе тиогидразидов оксаминовых кислот: автореф. дисс. на соискание ученой степени канд. хим. наук: - спец. 02.00 .03 «Органическая химия» / А. С. Никитина. - Москва, $2009 .-18$ с.

24. Renskyy M. A, Zyabrev V. S., Drach B. S. Zhurnal obshchey khimii, 2002, Vol. 72, No.11, pp.1931-1932.

25. Ренський М. О. Нові перетворення 1,2,4-тіадіазол-5(2н)-імінів та їх солей у похідні інших азотистих гетероциклів: автореф. дис. на здобуття вченого ступеня канд. хім. наук: спец. 02.00 .03 «Органічна хімія» / М. О. Ренський. - К., $2005 .-19$ с.

26. Krayushkin M. M., Yarovenko V. N., Sedishev I. P. et al. Mendeleev Commun., 2005, Vol. 15, No.4, pp.151-152.

27. Krayushkin M. M., Sedishev I. P., Yarovenko V. N. et al. Russ. J. Org. Chem., 2008, Vol. 44, No.3, pp.407-411.

28. Iaroshenko V. O., Volochnyuk D. M., Kryvokhyzha N. V. et al. Synthesis, 2008, Vol. 15, pp.2337-2346.

29. Artyomov V. A., Ivanov V. L., Shestopalov A. M. et al. Tetrahedron, 1997, Vol. 53, No.39, pp.13351-13360.

30. Иванов В. Л. Каскадные реакции в синтезе конденсированных пиридинов и пиримидинов: автореф. дисс. на соискание ученой степени канд. хим. наук: спец. 02.00.03 «Органическая химия» / В. Л. Иванов. - М., 1997. - 20 с.

31. Pat. DE 233010. - Publ. 03.01.1974. Chem. Abstr., 1974, Vol. 80, 95916 p.

32. Suzuki N., Dohmori R. Chem. Pharm. Bull., 1979, Vol. 27, No.2, pp. 410-418.

33. Couture A., Grandclaudon P., Huguerre E. J. Het. Chem., 1987, Vol. 24, No.6, pp.1765-1770.

34. Couture A., Huguerre E., Grandclaudon P. Synt. Comm., 1989, Vol. 19, No.3, pp.713-719.

35. Zhu L., Zhang M., Dai M. J. Het. Chem., 2005, Vol. 42, No.4, pp.727-730.

36. Kulkarni D. G., Lokhande S. R. Ind. J. Pharm., 1981, Vol. 43, pp.37-39.

37. Altland H. W., Molander G. A. J. Het. Chem., 1977, Vol. 14, No.1, pp.129-134.

38. Altland H. W. J. Org. Chem., 1976, Vol. 41, No.21, pp.3395-3398.

39. Pat. US 2005065151; Publ. 24.03.2005, http://www.espacenet.com.

40. Tsuruoka A., Kaku Y., Kakinuma H. et al. Chem. Pharm. Bull., 1998, Vol. 46, No.4, pp.623-630.

41. Smith K., Lindsay C. M., Morris J. K. Chem. Ind (London), 1988, pp.302-303.

42. Ma E. Molecules, 2003, Vol. 8, pp.678-686.

43. El-Hiti G. A. Monatshefte fuer Chemie, 2003, Vol. 134, No.6, pp.837-841.

44. Smith K., Anderson D., Matthews I. Sulfur Letters, 1995, Vol. 18, No.2, pp.79-95. 
45. Fridman S. G. Zhurnal obshchey khimii, 1956, Vol. 26, pp.613-617.

46. Fridman S. G. Zhurnal obshchey khimii, 1956, Vol. 26, pp.864-867.

47. Walczyn'ski K., Zuiderveld O. P., Timmerman H. European Journal of Medicinal Chemistry, 2005, Vol. 40, No.1, pp.15-23.

48. Gu and C. Jin L. Org. Biomol. Chem., 2012, Vol. 10, pp.7098-7102.

49. Couture A., Grandclaudon P. Heterocycle, 1984, Vol. 22, No.6, pp.1383-1385.

50. Kramberger L., Lorencak P., Polanc S. et al. J. Het. Chem., 1975, Vol. 12, No.2, pp.337-342.

51. Zavarzin I. V., Krayushkin M. M., Yarovenko V. N. et al. Russian Chemical Bulletin, 2004, No.6, pp.1299-1301.

52. Zavarzin I. V., Smirnova N. G., Yarovenko V. N. et al. Russ. Chem. Bull., 2004, Vol. 53, No.6, pp.1353-1354.

53. Смирнова Н. Г. Монотиооксамиды в синтезе конденсированных гетероциклических структур: автореф. дисс. на соискание ученой степени канд. хим. наук: спец. 02.00.03 «Органическая химия» / Н. Г. Смирнова. - М., 2006. - 20 с.

54. Заварзин И. В. Монотиооксамиды и тиогидразиды оксаминовых кислот в органическом синтезе: автореф. дисс. на соискание ученой степени докт. хим. наук: спец. 02.00 .03 «Органическая химия» / И. В. Заварзин. - М., 2009. - 48 с.

55. Matysiak J., Karpin'ska M., Niewiadomy A. et al. Chemistry \& Biodiversity, 2012, Vol. 9, No.1, pp.48-56.

56. Taeho Lee, Doohyun Lee, Ill Young Lee et al. J. Comb. Chem, 2010, Vol. 12, No.1, pp.95-99.

57. Shestopalov A. M., Rodinovskaya L. A., Shestopalov A. A. Tetrahedron, 2010, Vol. 66, No.46, pp.8945-8948.

58. Shestopalov A. M., Rodinovskaya L. A. Proceedings of the Fourth International Conference "Modern aspects of heterocyclic chemistry", St. Petersburg, 2010, pp.361-363.

59. Komaritsa I. D., Chaban I. G., German V. M. Pharmacevticheskoiy zhurnal, 1992, No.4, pp.39-43.

60. Al-Thebeiti Marzoog S. Il Farmaco. 2000, Vol. 55, pp.109-118.

61. Ulrich H. Georg Thieme Verlag: Stuttgart - New York, 2002, Vol. 11, pp.835-912.

62. El-Hiti G. A. Monatshefte fuer Chemie. 2003, Vol. 134, pp.837-841.

63. А.с. 1262931 СССР; заявл. 06.12.84 / ДСП.

64. А.с. 1282512 СССР; заявл. 14.06 .85 / ДСП.

65. Pat. WO2004011460 - Publ. 05.02.2004. Chem. Abstr., 2004, Vol. 140, 163862 p.

66. Pat. WO 2005037845. - Publ. 28.04.2005, No.WO 2004US34397. - http://www.espacenet.com.

67. Pat. WO 2004099204. - Publ.18.11.2004, N.WO2004SE00694. - http://www.espacenet.com.

68. Pat. WO 2004011460. - Publ. 05.02.2004. Chem. Abstr., 2004, Vol. 140, 63862 p.

69. Pat. WO 2009147431. - Publ. 10.12.2009, No.GB2009/050609. - http://www.espacenet.com.

70. Chaban T., Klenina O., Drapak I. et al. Ch\&ChT, 2014, Vol. 8 (3), pp.287-292.

71. Chaban T. I., Ogurtsov V. V., Komaritsa I. D. et al. Klinichna farmaciya, farmakoterapiya ta medychna standartyzaciya - Clinical pharmacy, pharmacotherapy and medical standardization, 2011, No.1-2, pp.208-213.

72. Klenina O. V., Chaban T. I., Ogurtsov V. V. et al. Zhurnal organichnoi ta farmacevtichnoi khimii - Journal of organic and pharmaceutical chemistry, 2014, Vol. 12, No.1(45), pp.60-68.

73. Pat. WO 2003101994. - Publ. 11.12.2003. Chem. Abstr., 2004, Vol. 140, 27845 p.

74. Kulkarni S. S., Newman A. H. Bioorg. Med. Chem. Lett., 2007, Vol. 17, pp.2987-2991.

75. Lin R., Johnson S. G., Connolly P. J. et al. Bioorg. Med. Chem. Lett., 2009, Vol. 19, pp.2333-2337.

76. Komoriya S., Kobayashi S., Osanai K. et al. Bioorg. Med. Chem., 2006, Vol. 14, pp.1309-1330.

77. Singh B., Bacon E. R., Lesher G. Y. et al. J. Med. Chem., 1995, Vol. 38, pp.2546-2550.

Надійшла до редакції 14.07.2014 р. 